\title{
Prevalence and factors associated with chronic wounds in older adults in primary care*
}

\author{
Prevalência e fatores associados a feridas crônicas em idosos na atenção básica \\ Prevalencia y factores asociados con heridas crónicas en ancianos en la atención básica
}

\author{
Chrystiany Plácido de Brito Vieira, Telma Maria Evangelista de Araújo²
}

How to cite this article:

Vieira CPB, Araújo TME. Prevalence and factors associated with chronic wounds in older adults in primary care. Rev Esc Enferm USP. 2018;52:e03415. DOI: http://dx.doi.org/10.1590/S1980-220X2017051303415

\footnotetext{
* Extracted from the thesis: "Prevalência de feridas crônicas e fatores associados em idosos na atenção básica”, Universidade Federal do Piauí, 2016.

${ }^{1}$ Universidade Federal do Piauí, Departamento de Enfermagem, Teresina, PI, Brazil.

${ }^{2}$ Universidade Federal do Piauí, Departamento de Enfermagem, Programa de Pós-Graduação em Enfermagem. Teresina, PI, Brazil.
}

\begin{abstract}
Objective: To analyze the prevalence of pressure injuries, diabetic and vasculogenic ulcers and associated factors in older adults attended in primary care. Method: A crosssectional, analytical study with older adults attended in the Family Health Strategy in a Brazilian municipality. Data collection was performed from January to March 2016 using interviews and evaluations of injuries. The variables were submitted to the multivariate logistic regression model using the odds ratio, with their respective $95 \%$ confidence intervals and significance set at $<0.05$. Results: 339 older adults participated in the study. The mean age was 71.1 years, $67.3 \%$ were female, $44 \%$ were illiterate, $85 \%$ had low family income, $91.7 \%$ had underlying diseases, $37.2 \%$ had dietary restrictions, and $76.1 \%$ did not practice physical activity. The prevalence of pressure injury was $5.0 \%$, diabetic ulcer $3.2 \%$, and vasculogenic ulcer $2.9 \%$. Not working and not regularly practicing physical activity increased the chances of presenting these injuries by 1.5 and 2.3 times, respectively. Being actively mobility and not having dietary restrictions were protective factors for not developing chronic wounds. Conclusion: The prevalence of injuries among older adults was high, and its occurrence is associated with socioeconomic and clinical characteristics.
\end{abstract}

\section{DESCRIPTORS}

Aged; Prevalence; Wounds and Injuries; Primary Health Care; Primary Care Nursing. 


\section{INTRODUCTION}

In Brazil, the increase in the aging population is a fact that worries professionals and managers of health care systems, since "the aging of the population is accompanied by an increase in the prevalence of diseases and chronic diseases"(1).

In this context and for definition purposes, chronic wounds are those that fail to advance in the ordered reparative process to produce anatomical and functional integrity over a period of 3 months. Among these we can highlight Pressure Injuries (PI), Diabetic Ulcers and Chronic Vasculogenic Ulcers $(\mathrm{CVU})^{(2)}$, which deserve special attention since they are more frequent and tend to be associated with common diseases in the older adult population, representing the problems that have been common in Brazilian public healthcare ${ }^{(3)}$.

The prevalence of chronic wounds varies according to conditions and etiologies, such as venous insufficiency, poor arterial perfusion, diabetes or high blood pressure ${ }^{(2)}$. In Brazil, studies indicate a high prevalence ${ }^{(4)}$ and incidence $^{(5-6)}$ of wounds in older adults living in institutions and during hospitalization. However, this problem is still little explored in older adults living in the community ${ }^{(1,7)}$. Thus, it is important to investigate this issue in basic care, since it constitutes a preferential door of access to care for older adults and a favorable scenario for actions to prevent and promote health since these injuries are avoidable, as well as for treatment and controlling actions considering the needs of the users ${ }^{(8)}$

Faced with this context and the reality experienced in the health scenario of the municipality of Teresina, PI, Brazil, as well as the need for information on the prevalence of these injuries in older adults attended in basic care, this study sought to analyze the prevalence of pressure injury, diabetic and vasculogenic ulcers and associated factors in older adults attended by the primary health care.

\section{METHOD}

A cross-sectional, analytical epidemiological study carried out in the basic health services of the city of TeresinaPiauí, an urban area in Brazil.

The study population consisted of people aged 60 years or over, residing in the urban area served by the Family Health Strategy (FHS) teams, belonging to the three Regional Health Departments (Diretorias Regionais de Saúde-DRS) of the municipality. The sample consisted of 339 older adults, selected by stratified proportional sampling in three stages. In the first stage, the proportional distribution of the number of older adults per department (DRS) was performed. In the second stage, the distribution was carried out proportionally to the number of Basic Health Units (Unidades Básicas de Saude - UBS) selected. In the third stage, the number of older adults was proportionally distributed per UBS, which were randomly selected using the R program (Project for Statistical Computing), version 3.0.2.
The considered variables were: socioeconomic variables (age, gender, schooling, family income, retirement and work activity status); clinical variables (diseases presented, continuous use of medication, locomotion, mobility, food intake, weight variation, Mini-Mental State exam score - MMSE, Katz score, smoking, alcoholism and practice of physical activity or not); characteristics of injuries (number of wounds, location, area, presence of exudate, tissue type, time, staging and Pressure Ulcer Scale for Healing - PUSH).

Data collection was performed either at the patient's home (if they had locomotion difficulty) or at the UBS, from January to March, 2016, using a Sociodemographic and Clinical Data Form, the MMSE, the Katz Scale and the PUSH Scale, according to an interview and a physical examination of the participants' skin.

The MMSE was initially applied to verify the cognitive conditions of the older adult to respond to the interview, and if the patient presented a score below the cut-off point, the exam was performed with the caregiver or the family member in charge who authorized it by signing the clear and Informed Consent Form (ICF). Otherwise, the older adults themselves answered the interview and signed the ICF. Differentiated cut-off points were used according to the educational level: 13 for illiterate, 18 for low (1 to 4 incomplete years of education) and average schooling (4 to 8 years of incomplete education), and 26 for high schooling ( 8 full or more years of education $)^{(9)}$.

The form was subsequently applied to survey variables related to sociodemographic, clinical and wound characteristics. The Katz Scale was used to evaluate functional independence to perform Basic Activities of Daily Living (BADL) according to different degrees of functional independence for each function: from 0 to 6 , in which from 0 to 5 it presents some degree of dependence ${ }^{(10)}$.

The PUSH was applied for characterizing the wound healing ${ }^{(11)}$. The classification of the international consensus of the National Pressure Ulcer Advisory Panel, the European Pressure Ulcer Advisory Panel and the Pan Pacific Pressure Injury Alliance ${ }^{(12)}$ for PI were used in order to classify the injuries; definitions recommended at the time of the project design and data collection; Wagner's classification for diabetic ulcers, which was used by Ministry of Health at the time of project design; and CVU and other chronic ulcers that did not meet the previous classifications were categorized according to the criterion of tissue loss.

\section{DATA ANALYSIS AND PROCESSING}

The statistical analysis implemented the Statistical Package for Social Science program $\left(\right.$ SPSS $^{\oplus}$ ), version 20.0. Descriptive statistics were calculated with position measures. In order to identify the associated factors, a bivariate analysis was initially performed, and only those with a value of $\mathrm{p} \leq 0.20$ (data not shown) were submitted to the multivariate logistic regression model using the adjusted odds ratio. The level of significance for rejection 
of the null hypothesis was set at $\mathrm{p} \leq 0.05$ and the confidence interval at $95 \%$.

\section{ETHICAL ASPECTS}

The study development met the standards of ethics in research involving human beings, in accordance with Resolution n. 466/12 of the National Health Council. The study was approved by the Research Ethics Committee of the UFPI, according to opinion number $1.346 .094 / 2015$.

\section{RESULTS}

The mean age of the participants was 71.1 years $(\mathrm{SD}=8.9)$, with a higher percentage of older adults in the age group between 60 and 70 years (55.8\%), predominantly female $(67.3 \%)$, with a partner $(54 \%)$ and no education (44\%). The majority $(72.3 \%)$ were retired, $13.9 \%$ had paid work, $26.3 \%$ did not work and $85 \%$ had a family income between 1 and 3 minimum wages, with an average of two people contributing to this income $(\mathrm{SD}=0.9)$, with an average of 3.8 people depending on it $(\mathrm{SD}=1.8)$.

Regarding clinical conditions, the majority (91.7\%) reported one or more underlying diseases, the most prevalent being arterial hypertension (70.1\%), 87.3\% continually used medication, $81.7 \%$ had preserved mobility and walked around, while $5.6 \%$ were bedridden. In relation to nutrition, $98.8 \%$ were fed orally and $37.2 \%$ had dietary restrictions due to socioeconomic conditions (restriction to certain foods and/or meals in the day). Among older adults with a high education level, $44.7 \%$ had cognitive deficits. It was observed that $83.5 \%$ were independent, and $89.8 \%$ among the dependents had a family caregiver. It was also found that only $9.4 \%$ were alcoholics and $23.9 \%$ routinely practiced physical activity.

Among the older adults interviewed, 40 presented a chronic wound; therefore, an estimated overall prevalence of $11.8 \%$ (95\% CI, 8.6-15.3), predominantly PI, with a prevalence of $5.0 \%$ (95\% CI, 2.9-7.7). Of these, 35\% had more than one injury, with an average of 1.4 wounds $(\mathrm{SD}=0.6)$ per patient (Table 1 ).

Table 1 - General prevalence and type of wound presented by older adult participants - Teresina, PI, Brazil, 2016.

\begin{tabular}{lcc}
\hline Variables & $\mathbf{n}(\%)$ & $\mathbf{9 5 \%} \mathbf{C l}$ \\
\hline Overall prevalence $^{(*)}$ & $40(11.8)$ & $8.6-15.3$ \\
PI prevalence & $17(5.0)$ & $2.9-7.7$ \\
CVU prevalence & $10(2.9)$ & $1.2-5.2$ \\
Diabetic ulcer prevalence & $11(3.2)$ & $1.5-5.3$ \\
\hline
\end{tabular}

Legend: ${ }^{*} 40$ cases, however two of them were related to other etiologies; $95 \% \mathrm{CI}=$ confidence interval.

A total of 54 injuries were analyzed: 28 (51.9\%) PI, 14 (25.9\%) diabetic ulcers and 12 (22.2\%) CVU. Regarding healing, the majority of PIs (71.4\%), diabetic ulcers
(78.6\%) and CVUs (75.0\%) had a PUSH score between 9 and 17 . In relation to the size, the majority of PI (64.2\%) and diabetic ulcers $(64.3 \%)$ had an area between $8.1 \mathrm{~cm}^{2}$ and $24.0 \mathrm{~cm}^{2}$, and $66.6 \%$ of CVUs were larger than 24 $\mathrm{cm}^{2}$. Regarding the evolution time, it was verified that both PI (89.2\%) and diabetic ulcers (85.8\%) were up to 12 months in most injuries, while most CVUs (66.6\%) were over 48 months (Table 2).

Table 2 - Distribution of wounds according to healing conditions - Teresina, PI, Brazil, 2016.

\begin{tabular}{|c|c|c|c|}
\hline \multirow{2}{*}{ Variables } & \multicolumn{3}{|c|}{ Type of wound n(\%) } \\
\hline & $\begin{array}{l}\text { Pressure } \\
\text { injury }\end{array}$ & Diabetic ulcer & $\begin{array}{c}\text { Vasculogenic } \\
\text { ulcer }\end{array}$ \\
\hline \multicolumn{4}{|l|}{ Area } \\
\hline $\begin{array}{l}0.3-1.0 \mathrm{~cm}^{2} \\
1.1-8.0 \mathrm{~cm}^{2} \\
8.1-24.0 \mathrm{~cm}^{2} \\
>24.0 \mathrm{~cm}^{2}\end{array}$ & $\begin{array}{l}03(10.8) \\
12(42.9) \\
06(21.3) \\
07(25.0)\end{array}$ & $\begin{array}{l}03(21.4) \\
02(14.3) \\
06(42.9) \\
03(21.4)\end{array}$ & $\begin{array}{c}02(16.7) \\
02(16.7) \\
- \\
08(66.6)\end{array}$ \\
\hline \multicolumn{4}{|l|}{ Exudate } \\
\hline $\begin{array}{l}\text { Absent } \\
\text { Little } \\
\text { Moderate } \\
\text { Much }\end{array}$ & $\begin{array}{l}06(21.3) \\
12(42.9) \\
05(17.9) \\
05(17.9)\end{array}$ & $\begin{array}{c}3(21.4) \\
05(35.8) \\
03(21.4) \\
03(21.4)\end{array}$ & $\begin{array}{l}05(41.6) \\
02(16.7) \\
03(25.0) \\
02(16.7)\end{array}$ \\
\hline \multicolumn{4}{|l|}{ Type of tissue } \\
\hline $\begin{array}{l}\text { Epithelium } \\
\text { Granulation } \\
\text { Slough } \\
\text { Necrotic }\end{array}$ & $\begin{array}{c}3(10.8) \\
9(32.2) \\
10(35.7) \\
06(21.3)\end{array}$ & $\begin{array}{c}01(7.1) \\
05(35.8) \\
07(50.0) \\
01(7.1)\end{array}$ & $\begin{array}{c}02(16.7) \\
02(16.7) \\
08(66.6) \\
-\end{array}$ \\
\hline \multicolumn{4}{|l|}{ Duration (months) } \\
\hline $\begin{array}{l}3-12 \\
13-48 \\
\geq 48\end{array}$ & $\begin{array}{c}25(89.2) \\
3(10.8) \\
-\end{array}$ & $\begin{array}{l}12(85.8) \\
01(7.1) \\
01(7.1)\end{array}$ & $\begin{array}{c}01(8.4) \\
03(25.0) \\
08(66.6)\end{array}$ \\
\hline \multicolumn{4}{|l|}{ PUSH } \\
\hline $\begin{array}{l}\leq 4 \\
5-8 \\
9-13 \\
14-17\end{array}$ & $\begin{array}{c}- \\
08(28.6) \\
10(35.7) \\
10(35.7)\end{array}$ & $\begin{array}{c}01(7.1) \\
02(14.3) \\
07(50.0) \\
04(28.6)\end{array}$ & $\begin{array}{c}02(16.7) \\
01(8.3) \\
03(25.0) \\
06(50.0)\end{array}$ \\
\hline
\end{tabular}

Note: $(\mathrm{n}=54)$

The body regions most affected by the wounds were sacral (all PI type), plantar region (80\% diabetic ulcers) and distal third of the leg (all CVU). The percentage of older adults with more than one injury was higher among those with PI (64.3\%), and single injuries predominated among those with CVU or diabetic injury. The majority of PIs (42.9\%) were stage 3, followed by stage 4 (32.1\%). Of the total diabetic ulcers, $64.3 \%$ were grade 1 and only $7.1 \%$ were classified as grade 4 since they presented gangrene located in the fingers. All CVU were of partial thickness, at different healing conditions.

Table 3 presents the variables that remained associated with chronic wound prevalence. Not performing any activity increased the chance of presenting chronic wound by 1.5 times, and not practicing physical activity increased the chances for the same event by 2.3 times. Being actively mobile and not having diet restriction had a negative association with wound development $(\mathrm{OR}=0.1$ and 0.3 , respectively). 
Table 3 - Multivariate analysis of the prevalence of chronic wounds and other independent variables - Teresina, PI, Brazil, 2016.

\begin{tabular}{|c|c|c|c|c|}
\hline & \multirow{2}{*}{ Independent variables } & \multicolumn{3}{|c|}{ Chronic wound } \\
\hline & & O.R. (adjusted) & p-value & $95 \% \mathrm{Cl}$ \\
\hline \multicolumn{5}{|c|}{ Age group } \\
\hline \multicolumn{5}{|c|}{$60-70\left(^{*}\right)$} \\
\hline $71-80$ & & 1.2 & 0.69 & $0.4-3.6$ \\
\hline$\geq 81$ & & 2.1 & 0.24 & $0.5-8.1$ \\
\hline \multicolumn{5}{|c|}{ Education (years) } \\
\hline None & & 1.7 & 0.46 & $0.4-7.3$ \\
\hline $1-3$ & & 1.6 & 0.53 & $0.3-8.6$ \\
\hline $4-7$ & & 5.2 & 0.07 & $0.8-32.6$ \\
\hline$\geq 8\left(^{*}\right)$ & & & & \\
\hline
\end{tabular}

Family Income (MW)

$\begin{array}{lllr}<1 & 6.1 & 0.99 & 0.1-6.6 \\ 1-3 & 0.69 & 0.59 & 0.1-2.5 \\ >3\left(^{*}\right) & & & \end{array}$

\begin{tabular}{llll}
\hline Average dependents on the family income & 1.1 & 0.48 & $0.8-1.2$ \\
\hline Work status & & $\mathbf{1 . 5}$ & 0.01 \\
None & & & \\
Domestic activities and/or other occupations $\left.{ }^{*}\right)$ & & \\
\hline
\end{tabular}

Physical activity

$\begin{array}{llll}\text { No } & 2.3 & 0.04 & 0.0-0.8\end{array}$

$\operatorname{Yes}(*)$

Weight variation

None $\left(^{*}\right)$

Weight gain

Voluntary weight loss

2.0

8.9

0.9

Involuntary weight loss

Mobility

Active $\left(^{*}\right)$

Moves with help

0.1

0.04

0-0.9

\section{Food intake}

No restriction $(*)$

Dietary restriction

Difficulty of food intake

0.3

0.04

$0.1-0.9$

0.2

0.16

$0-1.8$

Legend: O.R. $=$ adjusted odds ratio; $95 \% \mathrm{CI}=95 \%$ confidence interval; $\left(^{*}\right)=$ reference category. The $\mathrm{p}$-value was obtained by logistic regression. Note: $(n=40)$

\section{DISCUSSION}

The sociodemographic profile surveyed is in agreement with other national studies on the subject in question, such as the higher prevalence of the female population ${ }^{(7,13)}$ and lower education ${ }^{(14)}$.

Regarding the prevalence of chronic wounds, it is noteworthy that there is a paucity of epidemiological data in most countries, and it can be observed that there are large variations of this rate among the available data ${ }^{(15)}$. In Brazil, the statistical records on wounds in the population are still incipient, especially those of the chronic type ${ }^{(7)}$.

The prevalence found in this study was much higher than that observed in studies conducted in Germany and Ireland, 
which found chronic wound prevalence rates of $1.04 \%$ and $3.7 \%$, respectively ${ }^{(15-16)}$.

The high prevalence rate found in the present study can be explained by differences in the care characteristics in services in developed countries, such as the European services, which provide diagnostic conditions and treatment for rapid healing $^{(17)}$.

The most prevalent wounds in this study were PI, however with a lower rate than that found in a national study performed in households ${ }^{(18)}$. In Teresina, Piauí, a study that carried out a survey of the PI prevalence in bedridden patients enrolled in the FHS found a prevalence of $23.52 \%{ }^{(19)}$. There is also diversification of PI indexes internationally. In Spain, in 2013, a study found a PI prevalence of $0.44 \%$ (95\% CI, 0.41-0.47) in older adults over 65 years of age in the basic healthcare ${ }^{(20)}$. In Ireland, prevalences of $10 \%{ }^{(16)}$ and $16 \%{ }^{(21)}$ were observed in the community.

The prevalence of diabetic ulcers found was lower than that found in a study carried out in Brazil ${ }^{(22)}$, which showed prevalence of 5.9\%, and in Ireland with a rate of $4 \%{ }^{(16)}$. Studies in Brazil are scarce and punctual, especially in relation to those performed in primary care, which makes comparison difficult. It is important to note that there has been an increase in the prevalence of diabetic ulcers, mainly neuroischemic injuries, due to the age of the patients since as they grow older they develop more diabetic complications ${ }^{(23-24)}$.

The third highest prevalence was CVU, which differs from other studies ${ }^{(13,15)}$. Despite it not being the most prevalent, a high frequency of this type of injury in the older adult population surveyed was observed.

The prevalence of single injuries was also found in other studies $^{(7,13,16)}$. The highest proportion of patients with more than one injury was observed among older adults who presented PI, evidencing the persistence of risk factors, and possibly the absence of implementing protective measures. In the case of CVU, in which the majority was single injury, this may represent a phenomenon due to the long injury periods, which allowed a confluence of multiple injuries ${ }^{(25)}$, considering that the average evolution time of the wounds found was approximately 23 months.

A great variation was observed regarding the evolution time, which reinforces the interaction of factors for this aspect. We can point out that a longer duration increases the infection risk and the possibility of these ulcers recurring $^{(13)}$. In the case of CVU, 30\% are not likely to heal within 24 weeks, and therefore recognizing and identifying risk factors for delayed healing are beneficial for treatment success ${ }^{(26)}$.

The wound sites were related to their types. PIs more frequently affected the sacral region, which is associated with the position in which bedridden or wheelchairbound older adults remain, spending most of their time in dorsal decubitus or seated, leading to excessive pressure and PI development. These findings corroborate those of other studies ${ }^{(16,19)}$, which show that pressure and prolonged immobility are the main risk factors for developing PI.
Diabetic ulcers were predominant in the plantar region of the foot and toes, being similar to that in other studies $^{(13,27)}$. These sites are more subject to the common trauma in everyday life and are anatomically more susceptible to developing tissue necrosis ${ }^{(13)}$.

CVU were more common in the distal third of the leg, followed by the malleolar region; preferential ulcer regions with venous etiology and more prevalent among leg ulcers, as confirmed by the literature ${ }^{(13,20)}$.

It was verified that most wounds were large with a significant percentage of wounds above $24 \mathrm{~cm}^{2}$, and the presence of exudates, mostly with small and medium amounts (of exudate), being characteristic of chronic wounds pertaining to the inflammatory phase ${ }^{(2)}$. Regarding the tissue of the wound bed, the largest percentage was devitalized slough tissue, and compared to other studies ${ }^{(13,16)}$ we can verify that the participants in the present study generally had worse epithelialization conditions on the edges of the wounds.

Concerning wound stages, the majority of PIs were stages 3 and 4 . The injuries herein were found to be more severe and deeper compared to other studies, with persistent risk factors and possibly the absence of implementing protective measures $^{(16,18,20)}$.

Old age is associated with the occurrence of chronic wounds, regardless of its origin, as the probability of this occurrence doubles in people over 60 years of age ${ }^{(25)}$. This fact stems from problems inherent in aging itself, which increases the likelihood of mobility impairment, cardiovascular diseases and diabetes mellitus, being strong predictors for developing chronic wounds and delayed healing ${ }^{(27)}$.

Thus, several factors act synergistically in the risk of these injuries, such as clinical conditions and social and economic aspects ${ }^{(13)}$. The present study verified that chronic wounds remained associated with socioeconomic and clinical variables.

Regarding socioeconomic variables, wounds remained associated with performing some labor activity, whether domestic or paid, and dietary restriction (inadequate nutrition due to socioeconomic conditions). The majority of older adults did not perform any activity, and it was found that not developing any work activity increased the chances of this event occurring more than once. Older adults who maintain their activities of daily living and who work experience active aging and are healthier because they remain mentally and physically active, which improves performance in daily tasks and develops independence and autonomy, and paid work may have a protective effect on maintaining functional capacity in older adults ${ }^{(28)}$.

Having no dietary restriction represented a protective factor. In the studied sample, in which older adults predominated with low income and with retirement as the main source of income, inadequate nutrition was related to insufficient income, which makes it difficult to meet basic needs such as food.

Studies reinforce that an unfavorable economic condition is related to inadequate nutrition among older adults. In addition, inadequate intake of nutrients is common, since most of these individuals have comorbidities associated with 
various conditions, which may have an impact on adequate nutritional intake, which is necessary when an older adult presents with a chronic wound ${ }^{(27,29)}$.

In this study, chronic wounds continued to be associated with clinical variables and regular physical activity and active mobility. Regular physical activity has called attention in the context of aging, since the physiological changes that occur in this phase of human development, especially changes in blood circulation, decreased mobility, and decreased muscle tone, make older adults more likely to develop chronic wounds ${ }^{(19)}$. Thus, a lack of physical activity predisposes older adults to these injuries occurring, as it causes atrophy of the musculature and joints, and triggers related factors such as impaired physical mobility.

It is important to note that the presence of chronic wounds in older adults, especially diabetic ulcers or CVU, implies in greater difficulties in adhering to physical activity practice, since it causes pain and decreases the range of movements for long periods of time. In addition, we verified that impaired physical mobility in this group compromises the performance of domestic activities, limits the capacity of the individual and contributes to social isolation ${ }^{(8)}$, especially in cases where the wounds are beyond 48 months of evolution, as observed in this study.

Thus, impaired mobility was also associated with the occurrence of chronic wounds, since moving actively without assistance was a protective factor for not presenting this wound. Functional capacity, especially in the motor dimension, is one of the important markers of successful aging and quality of life in older adults. A long period of immobilization causes the disuse syndrome, thereby compromising several body systems ${ }^{(18)}$, which may explain the results found.
From this perspective, it is important to recognize that health conditions are not only the result of individual conditions, but of a number of factors in the care of older adults with chronic wounds. This care should primarily take place through primary care so as to avoid, or at least delay, hospitalizations which are costlier alternatives to health care. To do so, one must think of a set of structured care actions that not only pervade biological issues, but also social, cultural and economic barriers in order to meet the needs of older adults and improve health conditions ${ }^{(30)}$ based on the assessment of risks and health determinants.

The limitations of this study are related to the crosssectional design, which do not make it possible to establish a temporality relation, despite allowing for evidencing the factors associated with chronic wounds.

\section{CONCLUSION}

The prevalence of chronic wounds was $11.8 \%, 5 \%$ of PI, $3.2 \%$ of diabetic ulcers, and $2.9 \%$ of CVU. Not performing any labor activity and not performing regular physical activity presented an association with the prevalence of chronic wounds, while actively moving and not having dietary restriction were protective factors against developing wounds.

The presented and discussed data herein reinforce the role of clinical and socioeconomic aspects in the prevalence of PI, diabetic ulcer and CVU. Thus, we highlight the importance of elaborating prevention and treatment strategies in basic care, as well as the need for implementing Public Policies in the health care of people with chronic wounds, aiming at comprehensive and interdisciplinary care.

\section{RESUMO}

Objetivo: Analisar a prevalência de lesão por pressão, úlcera diabética e vasculogênica e fatores associados em idosos assistidos na atenção básica. Método: Estudo transversal, analítico realizado com idosos assistidos na Estratégia Saúde da Família, em um município brasileiro. A coleta de dados foi realizada de janeiro a março de 2016, utilizando-se de entrevista e avaliação das lesões. As variáveis foram submetidas ao modelo multivariado de regressão logística por meio do odds ratio, com seus respectivos intervalos de confiança de $95 \%$ e significância fixada em <0,05. Resultados: Participaram do estudo 339 idosos. A idade média foi de 71,1 anos, 67,3\% eram do sexo feminino, 44\% sem escolaridade, $85 \%$ com renda familiar baixa, $91,7 \%$ com doenças de base, $37,2 \%$ com restrição alimentar e $76,1 \%$ não praticavam atividade física. A prevalência de lesão por pressão foi 5,0\%, úlcera diabética 3,2\% e úlcera vasculogênica 2,9\%. Não desenvolver atividade laboral e não praticar atividade física regularmente aumentaram, respectivamente, em 1,5 e 2,3 vezes as chances de apresentá-las. Ter mobilidade ativa e não ter restrição alimentar foram fatores protetores para não desenvolver ferida crônica. Conclusão: A prevalência de feridas entre idosos foi elevada, e a sua ocorrência está associada às características socioeconômicas e clínicas.

\section{DESCRITORES}

Idoso; Prevalência; Ferimentos e Lesões; Atenção Primária à Saúde; Enfermagem de Atenção Primária.

\section{RESUMEN}

Objetivo: Analizar la prevalencia de lesión por presión, úlcera diabética y vasculogénica y factores asociados en personas mayores asistidas en la atención básica. Método: Estudio transversal, analítico, realizado con añosos asistidos en la Estrategia Salud de la Familia, en un municipio brasileño. La recolección de datos se realizó entre enero y marzo de 2016, utilizándose entrevista y evaluación de las lesiones. Las variables fueron sometidas al modelo multivariado de regresión logística mediante el odds ratio, con sus respectivos intervalos de confianza del 95\% y significación fijada en $<0,05$. Resultados: Participaron en el estudio 339 ancianos. La edad media fue de 71,1 años, el 67,3\% eran del sexo femenino, el 44\% sin escolaridad, el $85 \%$ con ingresos familiares bajos, el 91,7\% con enfermedades de base, el $37,2 \%$ con restricción alimentaria y el 76,1\% no practicaban actividad física. La prevalencia de lesión por presión fue del 5,0\%, úlcera diabética del 3,2\% y úlcera vasculogénica del 2,9\%. No desarrollar actividad laboral y no practicar actividad física regularmente aumentaron, respectivamente, en 1,5 y 2,3 veces las probabilidades de presentarlas. Tener movilidad activa y no tener restricción alimentaria fueron factores protectores para no desarrollar herida crónica. Conclusión: La prevalencia de heridas entre añosos fue elevada, y su suceso está asociados a las características socioeconómicas y clínicas.

\section{DESCRIPTORES}

Anciano; Prevalencia; Heridas y Lesiones; Atención Primaria de Salud; Enfermería de Atención Primaria. 


\section{REFERENCES}

1. Duim E, FHC Sá, YAO Duarte, RCB Oliveira, ML Lebrão. Prevalence and characteristics of lesions in elderly people living in the community. Rev Esc Enferm USP [Internet]. 2015 [cited 2016 Dec 10];49(n.spe):51-7. Available from: http://www.scielo.br/pdf/reeusp/v49nspe/ en_1980-220X-reeusp-49-spe-0051.pdf

2. Werdin F, Tennenhaus M, Schaller HE, Rennekampff HO. Evidence-based management strategies for treatment of chronic wounds. Eplasty [Internet]. 2009 [cited 2016 Dec 10];9:e19. Available from: https://www.ncbi.nlm.nih.gov/pmc/articles/PMC2691645/

3. Brito KKG, Sousa MJ, Sousa ATO, Meneses LBA, Oliveira SHS, Soares MJGO. Feridas crônicas: abordagem da Enfermagem na produção científica da pós-graduação. Rev Enferm UFPE [Internet]. 2013 [citado 2017 fev. 20]; 2(7):414-21. Disponível em: www.revista.ufpe.br/ revistaenfermagem/index.php/revista/article/download/.../5310

4. Freitas MC, Medeiros ABF, Guedes MVC, Almeida PC, Galiza FT, Nogueira JM. Úlcera por pressão em idosos institucionalizados: análise da prevalência e fatores de risco. Rev Gaúcha Enferm [Internet]. 2011 [citado 2016 fev. 10]; 32(1):143-50. Disponível em: http://www. scielo.br/pdf/rgenf/v32n1/a19v32n1.pdf

5. Luz SR, Lopacinski AC, Fraga R, Urban CA. Úlcera de pressão. Geriatr Gerontol. 2010;4(1):36-43.

6. Souza DM, De Gouveia Santos VL. Incidence of pressure ulcers in the institutionalized elderly. J Wound Ostomy Continence Nurs [Internet]. 2010 [cited 2016 July 10];37(3):272-6. Available from: https://www.ncbi.nlm.nih.gov/pubmed/20386329

7. Evangelista DG, Magalhães ERM, Moretão DIC, Stival MM, Lima LR. Impacto das feridas crônicas na qualidade de vida de usuários da Estratégia de Saúde da Família. Rev Enferm Cent Oest Min [Internet]. 2012 [citado 2016 ago. 10];2(2):254-63. Disponível em: http://seer. ufsj.edu.br/index.php/recom/article/view/15/308

8. Araújo RO, Silva DC, Souto RQ, Pergola-Marconato AM, Costa IKFC, Vasconcelos-Torres G. Impacto de úlceras venosas na qualidade de vida de indivíduos atendidos na atenção primária. Aquichán [Internet]. 2016 [citado 2018 maio 14];16(1):56-66. Disponível em: http:// www.scielo.org.co/scielo.php?script=sci_arttext\&pid=S1657-59972016000100007\&lng=en

9. Bertolucci PHF, Brucki SMD, Campacci SR, Juliano Y. O Mini-Exame do Estado Mental em uma população geral: impacto da escolaridade. Arq Neuro Psiquiatr [Internet]. 1994 [citado 2016 dez. 10];52(1):1-7. Disponível em: http://www.scielo.br/pdf/anp/v52n1/01.pdf

10. Lino VTS, Pereira SRM, Camacho LAB, Ribeiro Filho ST, Buksman S. Adaptação transcultural da Escala de Independência em Atividades da Vida Diária (Escala de Katz). Cad Saúde Pública [Internet]. 2008 [citado 2016 dez. 10];24(1):103-12. Disponível em: http://www.scielo. $\mathrm{br} / \mathrm{pdf} / \mathrm{csp} / \mathrm{v} 24 \mathrm{n} 1 / 09 . \mathrm{pdf}$

11. Santos VLCG, Azevedo MAJ, Silva TS, Carvalho VMJ, Carvalho VF. Adaptação transcultural do pressure ulcerscale for healing (PUSH) para a língua portuguesa. Rev Latino-Am Enfermagem [Internet]. 2005 [citado 2016 dez. 10];13(3):305-13. Disponível em: http://www.scielo. br/pdf/rlae/v13n3/v13n3a04.pdf

12. National Pressure Ulcer Advisory Panel, European Pressure Ulcer Advisory Panel and Pan Pacific Pressure Injury Alliance. Prevention and treatment of pressure ulcers: quick reference guide. Cambridge Media: NPUAP, EPUAP, PPPIA; 2009.

13. Oliveira BGRB, Castro JBA, Granjeiro JM. Panorama epidemiológico e clínico de pacientes com feridas crônicas tratados em ambulatório. Rev Enferm UERJ [Internet]. 2013 [citado 2016 dez. 10];21(n.esp.1):612-7. Disponível em: http://www.facenf.uerj.br/ v21nesp1/v21e1a09.pdf

14. Smaniotto PHS, Dalli R, Carvalho VF, Ferreira MC. Tratamento clínico das feridas: curativos. Rev Med [Internet]. 2010 [citado 2016 dez. 10];89(3/4):137-41. Disponível em: http://www.revistas.usp.br/revistadc/article/view/46287/49943

15. Heyer K, Herberger K, Protz K, Glaeske G, Augustin M. Epidemiology of chronic wounds in Germany: Analysis of statutory health insurance data. Wound Repair Regen. 2016;24(2):434-42. DOI: 10.1111/wrr.12387

16. O'Brien JJ, Moore Z, Connolly B, Concannon F, McLain N, Strapp H, et al. Exploring the prevalence and management of wounds in an urban area in Ireland. Br J Community Nurs. 2016;21 Suppl 3:S12-9.

17. Torres CV, Costa F, Medeiros IKS, Oliveira RKA, Souza AKG, Mendes AJP, et al. Caracterização das pessoas com úlcera venosa no Brasil e Portugal: estudo comparativo. Enferm Glob [Internet]. 2013 [citado 2016 dez. 10];(32):75-87. Disponível em: http://scielo.isciii.es/pdf/ eg/v12n32/pt_clinica5.pdf

18. Chayamiti EMPC, Caliri MHL. Pressure ulcer in patients under home care. Acta Paul Enferm [Internet]. 2010 [cited 2016 July 10]; 23(1):2934. Available from: http://www.scielo.br/pdf/ape/v23n1/en_05.pdf

19. Bezerra GC, Santos ICRV, Lima JC, Souza MAO. Avaliação do risco para desenvolver pé diabético na atenção básica. Rev Estima [Internet]. 2015 [citado 2017 mar. 20];13(3). Disponível em: https://www.revistaestima.com.br/index.php/estima/article/view/108

20. Pálsdóttir G, Thoroddsen A. Chronic leg ulcers among the Icelandic population. Ewma J. 2010;10(1):19-23.

21. Skerritt L, Moore Z. The prevalence, a etiology and management of wounds in a community care area in Ireland. Br J Community Nurs. 2014;Suppl:S11-7.

22. Ferrari DC, Monteiro ML, Malagutti W, Barnabe AS, Ferraz N, Ribeiro R. Prevalência de lesões cutâneas em pacientes atendidos pelo programa de internação domiciliar (PID) no município de Santos - SP. Consc Saúde [Internet]. 2010 [citado 2017 mar. 20]; 9(1):25-32. Dsiponível em: http://www.redalyc.org/articulo.oa?id=92915037004

23. Madanchi N, Tabatabaei-Malazy O, Pajouhi M, Heshmat R, Larijani B, Mohajeri-Tehrani MR. Who are diabeticfootpatients? A descriptivestudyon 873 patients. J Diabetes Metab Disord [Internet]. 2013 [cited 2017 Mar 20];12:36. Available from: https://www.ncbi. nlm.nih.gov/pmc/articles/PMC3708818/

24. Smanioto FN, Haddad MCFL, Rossaneis MA. Self-care into the risk factors in diabetic foot ulceration: cross-sectionalstudy. Online Braz J Nurs [Internet]. 2014 [cited 2016 July 10]; 13(3):343-52. Available from: http://www.objnursing.uff.br/index.php/nursing/article/ view/4680

25. Haji Zaine N, Burns J, Vicaretti M, Fletcher JP, Begg L, Hitos K. Characteristics of diabetic foot ulcers in Western Sydney, Australia. J Foot Ankle Res [Internet]. 2014 [cited 2016 July 10]; 7(1):39. Available from: https://www.ncbi.nlm.nih.gov/pmc/articles/PMC4182857/ 
26. Parker CN, Finlayson KJ, Shuter P, Edwards HE. Risk factors for delayed healing in venous leg ulcers: a review of the literature. Int J Clin Pract. 2015;69(9):967-77. DOI: http://dx.doi.org/10.1111/ijcp.12635

27. Gould L, Abadir P, Brem H, Carter M, Conner-Kerr T, Davidson J, et al. Chronic wound repair and healing in older adults: current status and future research. J Am Geriatr Soc [Internet]. 2015 [cited 2016 July 10];63(3):427-38. Available from: https://www.ncbi.nlm.nih.gov/ pmc/articles/PMC4582412/

28. D'orsii E, Xavier AJ, Ramos LR. Work, social support and leisure protect the elderly from functional loss: EPIDOSO Study. Rev Saúde Pública [Internet]. 2011 [cited 2016 July 10]; 45(4):685-92. Available from: http://www.scielo.br/pdf/rsp/v45n4/en_2626.pdf

29. Busato MA, Gallina LS, Teo CRPA, Ferrettia F, Pozzagnol M. Autopercepção de saúde e vulnerabilidade em idosos. Rev Baiana Saúde Pública [Internet]. 2014. [citado 2018 mai. 10]; 38(3):625-35. Disponível em: http://rbsp.sesab.ba.gov.br/index.php/rbsp/article/view/726

30. Veras RP, Caldas CP, Cordeiro HA. Modelos de atenção à saúde do idoso: repensando o sentido da prevenção. Physis [Internet]. 2013 [cited 2016 July 10];23(4):1189-13. Available from: http://www.scielo.br/pdf/physis/v23n4/09.pdf 